\title{
The Approbation of a Mathematical Model of the Influence of Three-Level Semantic Representation of an Educational Mes- sage on the Dynamics of Students' Creativity
}

\author{
Yelena Gafarova $^{1 *}$, Vladimir Belevitin ${ }^{1}$, Yuliya Korchemkina ${ }^{1}$, Yevgen Smyrnov $^{2}$, Marina Khasanova ${ }^{1}$ \\ ${ }^{1}$ South Ural State Humanitarian Pedagogical University,69, Lenina Avenue, 454080, Russian Federation \\ ${ }^{2}$ Stary Oskol Technological Institute n.a. A.A. Ugarov (branch) National University of Science and Technology "MISiS", 42 Makarenko \\ District, Stary Oskol, Russia \\ *Corresponding author E-mail: gafarovaea@cspu.ru
}

\begin{abstract}
The article presents the description and approbation experience of a mathematical model of three-level semantic representation of training signals. The results of approbation indicate a significant impact of the ternary nature of training signals on the dynamics of the changes in the verbal creativity indicator.
\end{abstract}

Keywords: mathematical model, creativity, ternary nature, educational message.

\section{Introduction}

In the studies of scientists of different directions [9, 11, 13, 15-16, 18-20], the trend, confirming the effectiveness of the ternary representation of information for the functioning of information systems of different nature, is identified.

Earlier, the authors experimentally tested the impact of the ternary nature of the modal format (visual, auditory and kinesthetic) of educational information on the process of learning and on the development of individual creativity of students [10]. The logical continuation of the research direction is to verify the influence of three-level semantic information representation and the approbation of a mathematical model for this test.

\section{Problem Statement}

The aim of this work is to present the experience of the approbation of a mathematical model of three-level representation of the semantics of communication messages in the educational process. One of the main objectives of educational communication in the teacher-student interaction is the task of informing the student of the content specified by curricula.

For the purposes of experimental verification, the authors have adapted the model proposed in [14]. Under an educational message, the verbal reproduction of the sense of educational material is understood.

To formalize the semantic content, let us divide the message into multiple semantic signals. Signals, in turn, will be divided into terms, and terms - into terminologies. Under a term, a training micromodule containing a cluster of concepts is understood.

The list that the sender - teacher intends to convey to the recipient - student will be called the set of signals of the educational message.

Thus, any message $\mathrm{M}$ is a complex of meaningful signals:

$$
M=\bigcup_{i=1}^{n} S_{i}
$$

Further, each signal is a set of $S_{i}$ terms $T_{i j}$, and each term, in turn, is a block of terminologies that express the concept of the term.

$$
\begin{gathered}
S_{i}=\bigcup_{j=1}^{n_{i}} T_{i j} \\
T_{i j}=\bigcup_{k=1}^{n_{i j}} t_{i j k},
\end{gathered}
$$

where $n$ is the number of signals in the message $M, n_{i}$ is the number of terms in the $i$-th signal, $n_{i j}$ is the number of terminologies in the $j$-th term of the $i$-th signal.

Thus, the ternary representation of educational information in the message from the teacher to the student is provided. More compactly, the relations (1) - (3) can be represented as:

$$
M=\bigcup_{i=1}^{n} S_{i} \bigcup_{j=1}^{n_{i}} T_{i j} \bigcup_{k=1}^{n i j} t_{i j k} .
$$

The main characteristic of the efficiency of the term (training micromodule) is the acceptance function $g_{i j}$ :

$$
g_{i j}=\operatorname{sgn} \sum_{k=1}^{n_{i j}} f_{i j k}
$$

where $f_{i j k}$ is the frequency of the term $t_{i j k}$ in the related to it term $T_{i j}$. It can be assumed for definiteness that in the educational process the term of the message can be accepted by the recipient - student 
as a whole, which would correspond to the full absorption of the educational material, accepted partially or not accepted at all. As a measure of signal reception, let us use the index $h_{i}$.

$$
h_{i}=\left(1 / n_{i}\right) \times \sum_{j=1}^{n_{i}} g_{i j},
$$

where $n_{i}$ is the number of signals.

Obviously, in the real educational process, the value of the measure of signal reception can vary from 0 to 1 .

Thus, formally the task is to establish a hypothetical relationship between individual characteristics of the measures of training signal reception in a ternary semantic representation and the indicators of students' creativity that are the receivers of such signals.

\section{The Solution of the Problem}

The base for the experimental test was the Federal State Budgetary Educational Institution of Higher Education "South Ural State Humanitarian Pedagogical University", training direction "Professional Training" in the field "Computer Science and Computer Facilities".

For experimental verification, preparatory work was carried out the research base was defined; the training material was redesigned to make it consistent with the mathematical model; the mathematical model of the experiment was adapted and elaborated; the diagnostic tool to conduct the study was selected.

Let us show by an example of one of the academic disciplines a three-level representation of the educational material. The discipline "Fundamentals of Information Security" contains the following training modules: "The Key Aspects and Issues of Formation of Information Security of a Modern Educational Organization", "Secure Information System", "Standardization in the Field of Information Security", "Technologies and Methods of Implementation of Information Security". For the section "Technologies and Methods of Implementation of Information Security", the decomposition for training sessions will be like this: "Cryptographic Methods of Information Security", "Protecting Information Infrastructure from Attacks", "Anti-Virus Protection", "Comprehensive Protection of Information Infrastructure and Resources". In turn, each named didactic unit (correlated with the signal (1)) is represented in the form of terms. For example, "Cryptographic Methods of Information Protection" will be the union of terms: "Encryption", "Steganographia", "Encoding", and "Compression".

The term "Encryption", in its turn, is presented in the form of a term list: symmetric and asymmetric encryption, substitution and permutation ciphers, encryption key, cipher cryptosecurity, Kerckhoffs's principles, combined ciphers, block ciphers, stream ciphers, encryption national standards.

For the assessment of creativity, the method of Tunik [17] was used, as well as the adaptation of the verbal and figurative battery of tests by E. Torrance with two generalized indicators of verbal and figurative creativity that had been widely used in psychological diagnostics of creative potential, creativity, personal and mental resource $[1-8,12]$. The dynamics of the changes in the generalized indicators of creativity were expressed in percentage.

For measuring the measure of signal reception (6), it was proposed to use regular evaluation sections of learning content expressed in scores, with the subsequent transfer of the share units.

At the end of the school year, the initial experimental data were obtained: the sets of average indicators of the reception signal measure for each student, the series of changes in the indicators of verbal creativity, and the trends of the indicators of imaginative creativity.

The null hypothesis $\left(H_{0}\right)$ was the assumption of the lack of communication between the indicators of signals reception and the indicators of creativity dynamics, while the average indicators of the measure of signal reception (6) correlated at first with the se- ries of changes in verbal creativity, and then with the series of changes in imaginative creativity. The hypothesis was tested by using Spearman's rank correlation coefficient.

Let us show by the example of one group of students (18 students) the calculation of Spearman's coefficient, where $X$ is considered as the measure of signal reception, and the variable $Y$ - the dynamics of change in verbal creativity. The results of the ranking of each of the geometric features $(X$ and $Y)$ are presented in Table 1 in ascending order.

Table 1: The ranking of geometric features $\mathrm{X}$ and $\mathrm{Y}$

\begin{tabular}{|c|c|c|c|c|c|c|}
\hline $\mathrm{N}$ & $X$ & $\begin{array}{c}\text { Rank, } \\
R_{x}\end{array}$ & $Y$ & $\begin{array}{c}\text { Rank, } \\
R_{y}\end{array}$ & $\begin{array}{c}\text { The difference of ranks } D, R_{x} \\
-R_{y}\end{array}$ & $D^{2}$ \\
\hline 1 & 0.785 & 11 & 14.5 & 10 & 1 & 1 \\
\hline 2 & 0.774 & 7.5 & 13.7 & 3 & 4.5 & 20.25 \\
\hline 3 & 0.782 & 10 & 13.8 & 4 & 6 & 36 \\
\hline 4 & 0.663 & 3 & 11.2 & 1 & 2 & 4 \\
\hline 5 & 0.665 & 4 & 14.4 & 9 & -5 & 25 \\
\hline 6 & 0.658 & 2 & 12.3 & 2 & 0 & 0 \\
\hline 7 & 0.632 & 1 & 15.5 & 11 & -10 & 100 \\
\hline 8 & 0.854 & 16 & 17.3 & 15 & 1 & 1 \\
\hline 9 & 0.883 & 18 & 18.8 & 18 & 0 & 0 \\
\hline 10 & 0.821 & 13 & 18.1 & 17 & -4 & 16 \\
\hline 11 & 0.832 & 14.5 & 16.5 & 12 & 2.5 & 0.25 \\
\hline 12 & 0.774 & 7.5 & 14.2 & 7 & 0.5 & 0.25 \\
\hline 13 & 0.721 & 5 & 13.9 & 5 & 0 & 0 \\
\hline 14 & 0,753 & 6 & 14.0 & 6 & 0 & 0 \\
\hline 15 & 0.776 & 9 & 14.3 & 8 & 1 & 1 \\
\hline 16 & 0.882 & 17 & 17.9 & 16 & 1 & 1 \\
\hline 17 & 0.832 & 14.5 & 17.1 & 13.5 & 1 & 2.25 \\
\hline 18 & 0.812 & 12 & 17.1 & 13.5 & -1.5 & 1 \\
\hline
\end{tabular}

The formula for calculating Spearman's correlation coefficient $p$ was used in the form:

$$
p=1-\frac{6 \times \sum_{i=2} D_{i}^{2}-A-B}{\sqrt{\left(n^{3}-n-12 A\right) \times\left(n^{3}-n-12 B\right)}},
$$

where $A$ was the correction for the connectives of ranks in the row $X, B$ was the correction for the connectives of ranks in the row $Y$. To calculate corrections, the formulas were used:

$A=\frac{1}{12} \sum_{j}\left(A_{j}^{3}-A_{j}\right)$

where $j$ was the number of the connective in the row $X ; A_{j}$ was the number of equal ranks in conjunction with the number $j$.

$$
B=\frac{1}{12} \sum_{k}\left(B_{k}^{3}-B_{k}\right)
$$

where $k$ was the number of the connective in the row $Y ; B_{k}$ was the quantity of equal ranks in connection with the number $k$

Calculations by the formulas (8-9) were as follows: correction $A=1$, correction $B=0.5$, the sum of squares of differences of ranks $\sum D^{2}=215$. By the substitution of the obtained values into the formula (7), one can find the value of Spearman's correlation coefficient: $p=1-(6 \times 215-1-0.5) / \operatorname{sqrt}((5,832-18-12 \times 1) \times$ $(5,832-18-12 \times 0.5))=0.778$.

To check the assessment of the significance of the obtained Spearman's rank correlation coefficient $p$, Student's criterion was used.

The significance of the rank correlation coefficient $T_{r}$ is as follows:

$$
T_{p}=p \times \frac{\sqrt{(m-2)}}{1-p^{2}}=0.778 \times 4 /\left(1-0.778^{2}\right)=7.8856
$$


If $T_{r}>t_{t a b l}=2.12$, then the hypothesis $H_{0}$ on the absence of correlation between samples is rejected and the alternative hypothesis on the statistical significance of the difference in the correlation coefficient from zero and the existence of the link is accepted.

For the other two groups, the values of $p$ amounted to 0.635 and 0.811 , with the statistical significance of difference established by validation using Student's criterion.

When comparing the measure of signal reception and the dynamics of the imaginative creativity indicator, the values of Spearman's coefficients amounted to: $0.221,0.336$, and 0.478 , while the statistical significance of the difference was not confirmed by Student's criterion.

\section{Conclusion (Findings)}

1. The problem of approbation of a mathematical model of the impact of three-level semantic representation of an educational message to increase the dynamics of changes in students' creativity was formulated and solved in this paper.

2. A statistically significant link between the measure of signal reception and the dynamics of the increase in the verbal creativity indicator was identified.

3. No statistically significant link between the measure of signal reception and the dynamics of the change in the verbal creativity indicator was identified.

\section{References}

[1] Dorfman, L. Ya. (2015) Urovni i tipy kreativnosti: analiz sovremennykh psikhologicheskikh kontseptsii [Levels and Types of Creativity: Analysis of Modern Psychological Concepts]. Psikhologicheskii zhurnal, 36 (1), pp: 81-90.

[2] Herrmann, D. \& Felfe, J. (2013) Moderators of the Relationship Between Leadership Style and Employee Creativity: the Role of Task Novelty and Personal Initiative. Creativity Research Journal, 25 (2), pp: 172-181.

[3] Jaussi, K. S. \& Randel, A. E. (2014) Where to Look? Creativite Self-Efficacy, Knowledge Retrieval and Incremental and Radical Creativity. Creativity Research Journal, 26 (4), pp: 400-410.

[4] Kholodnaya, M. A. (2015) Intellekt, kreativnost, obuchaemost: resursnyi podkhod (o razvitii idei V.N. Druzhinina) [Intellect, Creativity, Learning Ability: Resource Approach (About Development of Ideas of V.N. Druzhinin)]. Psikhologicheskii zhurnal, 36 (5), pp: 5-14.

[5] Kholodnaya, M. A., Shcherbakova, O. V., Gorbunov, I. A., Golovanova, I. V. \& Papovyan, M. I. (2013) Informatsionnoenergeticheskie kharakteristiki razlichnykh tipov kognitivnoi deyatelnosti [Information and Energy Characteristics of Various Types of Cognitive Activities]. Psikhologicheskii zhurnal, 34 (5), pp: 96-107.

[6] Li, Y.-H., Tseng, C.-Y., Huang, A. C.-W., Lin, W.-L. \& Tsai, A. C.-H. (2016) Different Brain Wave Patterns and Cortical Control Abilities in Relation to Different Creative Potentials. Creativity Research Journal, 28 (1), pp: 89-98.

[7] Pinheiro, I. R. \& Cruz, R. M. (2014) Mapping Creative: Creativity Measurements Network Analysis. Creativity Research Journal, 26 (3), pp: 263-275.

[8] Razumnikova, O. M. \& Volf, N. V. (2015) Creativity-Related Hemispheric Selective Processing: Correlations on Global and Local Levels of Attentional Set. Creativity Research Journal, 27 (4), pp: 394-399.

[9] Barsht, K. A. (2011) O trinitarnoi strukture khudozhestvennoi kommunikatsii i polivergentnoi modeli so-bytiinosti ("Sluchai" D. Kharmsa i "Rakovina" O. Mandelshtama) [On the Trinitarian Structure of the Artistic Communication and Polyvergent models of Eventfulness ("Cases" by D. Kharms and "Shell" by O. Mandelstam)]. Narratorium, 1-2. Retrieved June 20, 2017, from http://narratorium.rggu.ru/article.html?id=2027586.

[10] Belevitin, V.A., Gafarova Ye.A., Korchemkina, Yu. V. \& Schwarzkop, O.N. (2017) Vliyanie ternarnosti predstavleniya uchebnoi informatsii na povyshenie kreativnosti obuchayushchikhsya [The Influence of Ternary Presentation of Educational In- formation on the Increase of Students' Creativity]. European Social Science Journal, 6, pp: 194-200.

[11] Bellyustin, N. S. \& Kovalchuk, A. V. (2013) Razrabotka adaptivnogo bazovogo klassifikatora dlya kognitivnoi sistemy [The Development of Adaptive Base Classifier for Cognitive System]. In Sb. nauchnykh trudov III Vserossiiskoi konferentsii "Nelineinaya dinamika v kognitivnykh issledovaniyakh" [Collection of Scientific Works of the 3rd All-Russian Conference "Nonlinear Dynamics in Cognitive Studies"] (pp. 122-134). Nizhny Novgorod.

[12] Gafarova, Ye. A. (2016) Razvitie kreativnosti putem rasshireniya raznoobraziya modalnogo opyta obuchaemogo [The Development of Creativity through Increased Diversity of the Student's Modal Experience]. Diskussiya, 6 (69), pp. 121-129.

[13] Kalinin, P. Ye. (2011) Stanovlenie statiko-dinamichnogo i kontinualno-diskretnogo edinstva $\mathrm{v}$ deyatelnosti soznaniya: diss. na soiskanie uchenoi stepeni kandidata filosofskikh nauk [The Formation of the Static-Dynamic and Continuous-Discrete Unity of Consciousness Activity (Ph. D. Thesis)]. Retrieved June 20, 2017, from: http://www.dissercat.com/content/stanovlenie-statikodinamichnogo-i-kontinualno-diskretnogo-edinstva-v-deyatelnostisoznaniya.

[14] Mosin, V. G. (2010) Semantika vizualnykh kommunikatsii [The Semantics of Visual Communications]. Izvestiya Samarskogo nauchnogo tsentra RAN, 3-3. Retrieved July 03, 2017, from https://cyberleninka.ru/article/n/semantika-vizualnyhkommunikatsiy.

[15] Ngoc Nguyen Ba \& Tuzovskii, A. F. (2013) Model informatsionnogo poiska na osnove semanticheskikh metaopisanii [The Model of Information Search Based on Semantic Metadescriptions]. Up ravlenie bolshimi sistemami, 41. Retrieved July 3, 2017, from https://cyberleninka.ru/article/n/semantika-vizualnyhkommunikatsiy.

[16] Petrov, V. M. (2008) Ternarnost v myshlenii, kulture, iskusstve: sistemno-informatsionnye korni bessoznatelnogo [Ternary Nature in Thinking, Culture, and Art: System Information Roots of the Unconscious]. Psikhologiya. Zhurnal VShE, 5 (4), pp. 3-18. Retrieved June 20, 2017, from http://www.vash-psiholog.info/ psihologiya/17453-ternarnost-v-myshlenii-kulture-iskusstve-sistemnoinformacionnye-korni-bessoznatelnogo.html.

[17] Tunik, Ye. Ye. (2013) Luchshie testy na kreativnost. Diagnostika tvorcheskogo myshleniya [The Best Tests for Creativity. Diagnostics of Creative Thinking]. St. Petersburg: Piter, 320 p.

[18] Fedotov, N. G., Kolchugin, A. S., Smolkin, O. A. \& Romanov, S. V. (2007) Tripletnye priznaki raspoznavaniya slozhnostrukturirovannykh, semanticheski nasyshchennykh izobrazhenii [Triplet Signs of Recognition of Complex, Semantically Rich Images]. Izvestiya VUZov. Povolzhskii region. Tekhnicheskie nauki, 1. Retrieved July 3, 2018, from https://cyberleninka.ru/article/n/ tripletnye-priznaki-raspoznavaniya-slozhnostrukturirovannyhsemanticheski-nasyschennyh-izobrazheniy.

[19] Chashchina, S. V. (2000) Kontseptsiya muzykalnoi dlitelnosti: na primere instrumentalnogo tvorchestva Kloda Debyussi: diss. na soiskanie stepeni kandidata iskusstvovedeniya [The Concept of Music Duration: By the Example of Instrumental Works by Claude Debussy (Ph. D. Thesis)]. St. Petersburg. Retrieved June 20, 2017, from: http://www.dissercat.com/content/kontseptsiya-muzykalnoidlitelnosti-na-primere-instrumentalnogo-tvorchestva-klodadebyussi

[20] Shazhinbat, A. (2016) Etnos kak filosofsko-antropologicheskaya problema: dissertatsiya na soiskanie stepeni doktora filosofskikh nauk [Ethnicity as a Philosophical-Anthropological Issue (Doctoral Thesis)]. Moscow: Institute of Philosophy of RAS, 359 p. 